\title{
Formation of the Japanese Colonial City of Dalian: A Focus on the Backgrounds of Successful Japanese Businessmen and Elites
}

\author{
NAKANISHI Ryotaro \\ Faculty of Humanities and Social Sciences, University of Tsukuba; Tsukuba 305-8571, Japan. \\ E-mail: nakanishi.ryotaro.fm@u.tsukuba.ac.jp
}

Received May 31, 2015; Accepted December 17, 2015

Abstract In this study, I elucidate the regional relationship between the mainland and the Japanese colonial city of Dalian. For this research, I focus on the backgrounds of contemporary influential figures: successful Japanese businessmen and other social elites, including the merchants, manufacturers, and senior officials of the South Manchuria Railway Company. For the time frame of the study, I used the Who's Who of Japanese living in Manchuria; Manshushinshi-shinshoroku edited in 1926 and published in 1927. This book listed 427 persons living in Dalian along with their occupations and careers. These people can be classified into two groups based on their educational background: the highly educated and the less educated, many of whom hailed from hometowns in western Japan. Among highly educated people, their schools were catalysts as a central turning point and their location played a pivotal role in their lives; herein, their life was related with Dalian, and schools in Tokyo were especially significant. In contrast, the locus of the professional turning points for less-educated people was the place of employment: the store (or company) where they worked or the business that they had initiated; Osaka-Kobe area became the most significant area for them. Many of the less-educated people traveled to Dalian after working in Osaka-Kobe area. Approximately 30 percent of the total population under study had worked abroad, mainly in other Japanese colonies, before coming to Dalian.

Key words colonial city, Dalian, Who's Who, successful Japanese businessmen, South Manchuria Railway Company

\section{Introduction}

When we think about the regional organization of modern Japan from a historical geographic perspective, the colonial areas (Korea, Taiwan, Sakhalin, and Manchuria) are symbolic because they don't exist as Japanese territories today, but did exist as such in early modern times; they represent "modernity" itself. In this study, I focus on Dalian, which is located at the top of the Liaodong peninsula and served as a gateway from the sea to Manchuria during that period (Figure 1).

Dalian was founded by Russia, but after the RussoJapanese War (1904-1905), it was ruled by Japan and developed as an international port city. The population of Dalian increased to about 200,000, including 80,000 Japanese, by the late 1920s. In those days, the total Japanese population of Manchuria was approximately 200,000; the next large city where many Japanese lived was Mukden, and its population was 20,000. In this way, Dalian was the city consisting of the highest Japanese population in Manchuria. So, when we think about the colony city formation of Manchuria by the Japanese, it may be said that Dalian is a representative city. In addition, in the Japanese Manchurian management, the South Manchuria Railway Company (also known as Mantetsu), played a very important role economically, and the transportation of supplies and persons by the railroad was tied to Dalian Port. Dalian played the role of a node of ground transportation and traffic on the seas in Manchuria. Because of its important geographical location, the main office of Mantetsu was set in Dalian, and it was an industrial city in Mantetsu.

The purpose of this study is to clarify what kind of people made Dalian such a Japanese colony and elucidate the regional relationship between the mainland and Dalian, paying attention to an aspect of the population movement that I watched through the life course approach. In order to achieve this purpose, I focus on the backgrounds of successful Japanese businessmen and other social elites, including merchants, manufacturers, and senior officials of the South Manchuria Railway Company by using the Who's Who of Japanese living in Manchuria, since they were influential in urban society at that time.

In this study, I used the Who's Who Manshu-shinshi- 


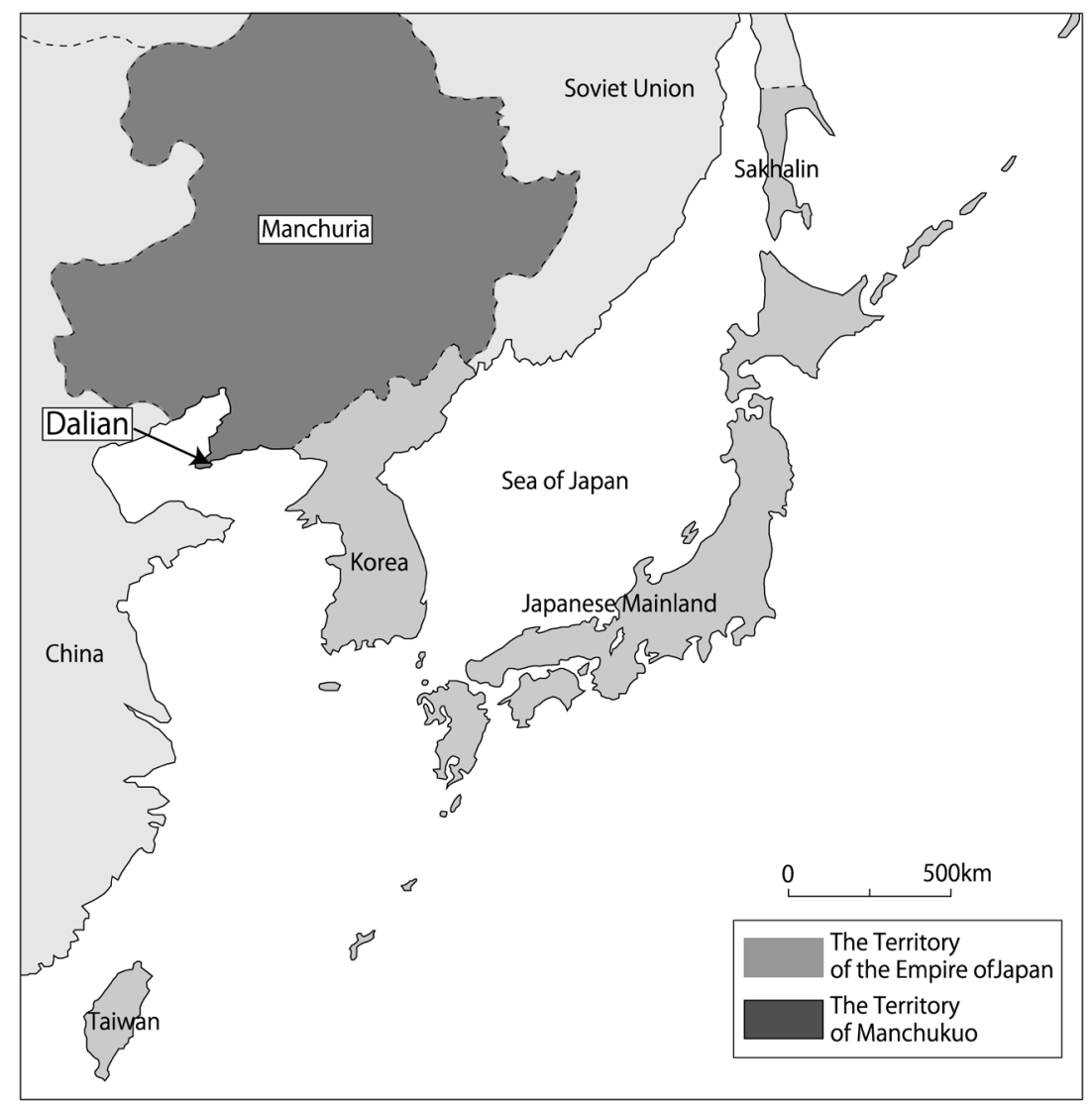

Figure 1. Location of Japanese colonial city Dalian (1935).

shinshoroku, which was published in April 1927 by the Japanese-Chinese detective agency in Dalian. This book was edited in 1926, and thus, we can consider this to contain the contents of the year. I used this book because it was edited approximately 20 years after the RussoJapanese War, when the city formation by the Japanese had considerably advanced.

As for this book, the persons living in the then Kanto State were collected, and it was divided into two parts: Dalian and its suburbs, Ryojun and Kinshu. The total number of people recorded in this book was 478, of whom 427 people were living in Dalian and its suburbs. In this study, I treated the 427 people as the Japanese who lived in Dalian.

In this book, the career is also mentioned along with the date of birth and birthplace of each person, present address, and occupation in detail. Such a Who's Who was a record of successful men in those days and not of the common people, and the activities of each person were expressed exaggeratedly. However, it is considered that the information of the birthplace and the career do not contain any errors.

Using Who's Who, first, I specifically examined the types of business of the Japanese elites and their socioeconomic positions. Second, I noted where these individuals were born and raised and the type of work they engaged in before becoming influential in Dalian, while making note of the opportunities and locales that led them to the colonial city. Finally, I clarified the regional relationship between the mainland and its colony in modern Japan.

In recent years, the studies about Manchuria are flourishing in Japan. But not many studies exist in this geographical field. In such a situation, I can nominate Mizuuchi (1985), Avila-Tàpies (2002, 2003, 2004, 2013), Nakanishi (2006), Miki (2013) for substantial geographical studies about Manchuria. In these studies, AvilaTàpies (2002) covers Japanese emigration and fixation pattern to Manchuria. Therefore, at the point of population movement, this study is closely related to our current study. However, Avila-Tàpies (2002) covers the entire Manchuria region and did not pay attention to the formation of Dalian city.

Many studies have been conducted on Dalian, but the only one on historical geography is Mizuuchi (1985). This study surveyed the developmental process of Dalian as a Japanese colonial city and examined its residential segregation by economic and social status. An important study of the Japanese merchants and manufacturers in Dalian is Yanagisawa (1999). He gave a detailed account of their activities, in chronological order, from the perspective of socio-economic history. But those studies did not address 
the problems addressed by the current study.

Tsukase (2004) utilizes Who's Who and clarifies Japanese life before World War II in Manchuria, including Dalian. In this study, there is much knowledge concerning the current study including the constitution of Japanese occupation and population movement, but it is not a study that paid attention to the life course of people.

Komine (2010) also conducted a study of Who's Who of Japanese living in Manchuria. Using Manshushinshiroku published from 1907 to 1908, his study examined life courses by generation. Komine's study provided many important strategies and methods for analyzing Who's Who. His main interest, however, was in individual life courses rather than trends in regions such as Manchuria or Dalian.

As mentioned above, no study exists that deals with population movement through life courses by using Who's Who to elucidate the formation of the city in Manchuria; the current study is original in this respect.

\section{Age Composition and Educational Background}

To determine the age ranges of those in Who's Who, I sorted their ages by birth years at five-year intervals. Their ages were then calculated by the year the book was edited. As shown in Figure 2, the ages of the main members recorded in Who's Who were in the late 30 s and 40 s (born between 1875 and 1889). The oldest was 72, and the youngest was 26 years.

Furthermore, I considered it important to classify into two groups based on their educational background: the highly educated and the less educated. I classified the highly educated as those who had graduated from university, college, higher professional school, high school, or had an equivalent educational record. (It should be noted that high school during that time was comparable to college today.) The highly educated numbered 249, and the less educated numbered 178. Demographic analysis showed that the younger the age bracket, the higher the proportion of highly educated people.

\section{Kinds of Business}

Table 1 indicates the composition of their types of businesses. Mantetsu indicates a senior official of South Manchuria Railway Company above manager level, including doctors in Mantetsu's hospital. Those in this classification numbered 56, and all were highly educated. The number of employees or owners of trading companies was 43. Among these, highly educated people were more numerous than less-educated people. The number of owners and employees in independent stores was 73 . Most of these were independent managers and less-educated people. The number of those working in transport industries, primarily in maritime traffic, was 20. Doctors and lawyers in private practice numbered 36 , and all were highly educated. Manufacturers numbered 40, and the number of elites of civil engineering and construction was 28 . The number of government officials was 15 , and most of these were highly educated.

Furthermore, many people were not senior officials in

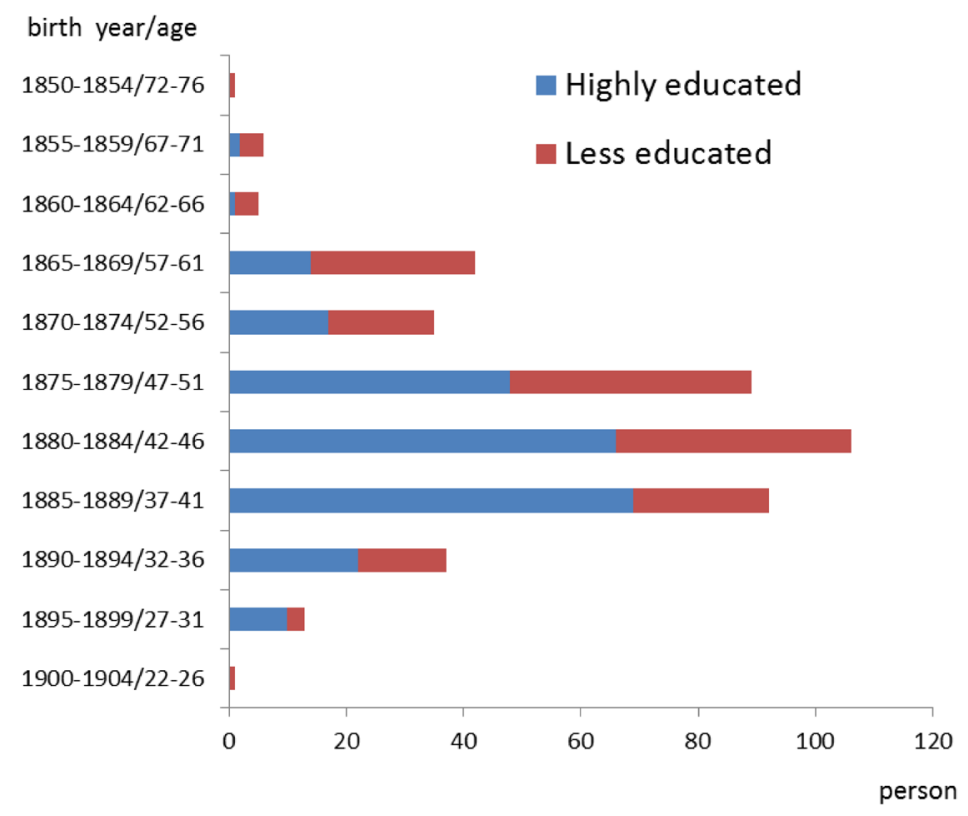

Figure 2. Age composition and educational background.

Source: Manshu-shinshi-shinshoroku. 
Table 1. Kinds of Business

(person)

\begin{tabular}{|c|c|c|c|c|c|}
\hline \multirow{2}{*}{ Occupation/Employment } & \multirow{2}{*}{ Employee } & \multirow{2}{*}{ Independent } & \multirow{2}{*}{ Sum } & \multicolumn{2}{|c|}{ Educational background } \\
\hline & & & & Highly educated & Less educated \\
\hline Mantetsu & 56 & 0 & 56 & 56 & 0 \\
\hline Trading Company & 24 & 19 & 43 & 24 & 19 \\
\hline Store & 5 & 68 & 73 & 10 & 63 \\
\hline Bank & 14 & 1 & 15 & 12 & 3 \\
\hline Securities/Finance & 5 & 12 & 17 & 4 & 13 \\
\hline Transport industries & 8 & 12 & 20 & 13 & 7 \\
\hline Newspaper office & 19 & 0 & 19 & 13 & 6 \\
\hline Lawyer & 0 & 16 & 16 & 16 & 0 \\
\hline Doctor & 0 & 20 & 20 & 20 & 0 \\
\hline Manufacturer & 23 & 17 & 40 & 22 & 18 \\
\hline Civil engineering and Construction & 3 & 25 & 28 & 10 & 18 \\
\hline Government official & 15 & 0 & 15 & 13 & 2 \\
\hline Others & 40 & 25 & 65 & 36 & 29 \\
\hline Total & 212 & 215 & 427 & 249 & 178 \\
\hline
\end{tabular}

Source: Manshu-shinshi-shinshoroku.

Mantetsu in 1926, but had previously been affiliated with Mantetsu. Figure 3 shows the numbers of employees and former employees of Mantetsu by age brackets. Former employees of Mantetsu numbered 68; added to the 1926 workforce of Mantetsu, this totals 124 people. This means 29 percent of all of them were affiliated with Mantetsu in 1926 or before. Most of these individuals were under 50 years old because Mantetsu was established in 1906.

\section{Arrival Dates in Dalian and Their Relationship to the Russo-Japanese War}

Figure 4 shows by year the number of elites who came to Dalian for the first time for business. The blue line shows the changes in the total number of elites, the red line shows the number of less educated, and the green line shows the number of highly educated. The number of less-educated newcomers increased rapidly in 1905, after the Russo-Japanese War, but decreased rapidly and remained at a low level afterwards. This is because just after the war, many had envisioned business success in Dalian or Manchuria but soon found this hope unrealistic. The number of highly educated newcomers increased rapidly in 1907 because this was the year Mantetsu started to recruit many employees. After that year, the numbers remained moderate.

Figure 5 shows the number of people involved in the Russo-Japanese War by age bracket. These included soldiers, army civilians (for example, engineers or transla-

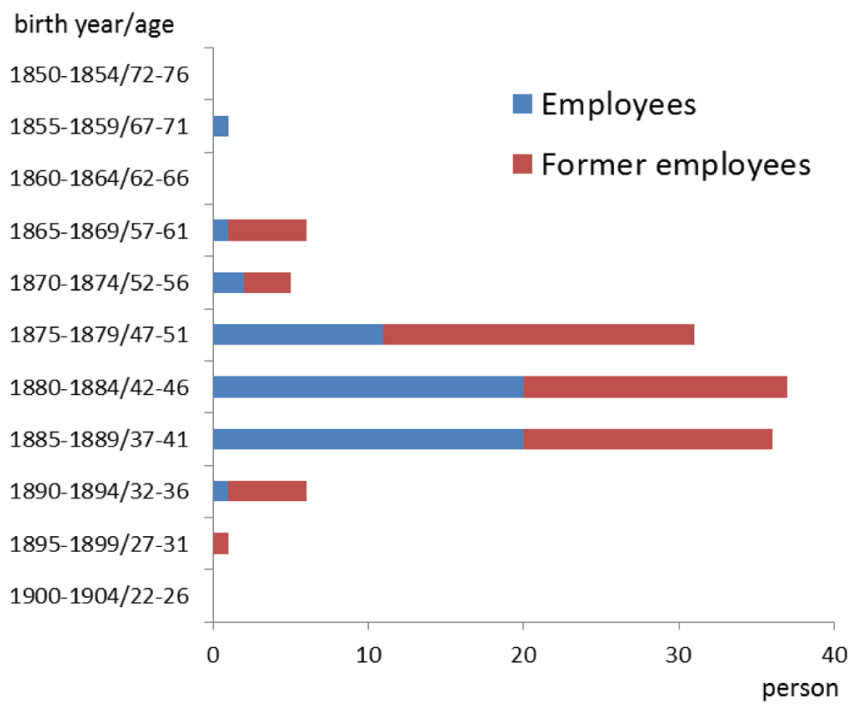

Figure 3. Employees of Mantetsu. Source: Manshu-shinshi-shinshoroku.

tors), and army brokers. The total number of people was 57. From this data, it appears that as low-educated people became familiar with Manchuria through their war experiences, many of them began to return to Dalian for business.

\section{Hometown, Career, and Pivotal Locations}

Figure 6 shows the hometowns of highly educated people by prefecture. The left side indicates the number of people, and the right indicates the number per 1000 persons using the 1920 census. As a regional trend, more 


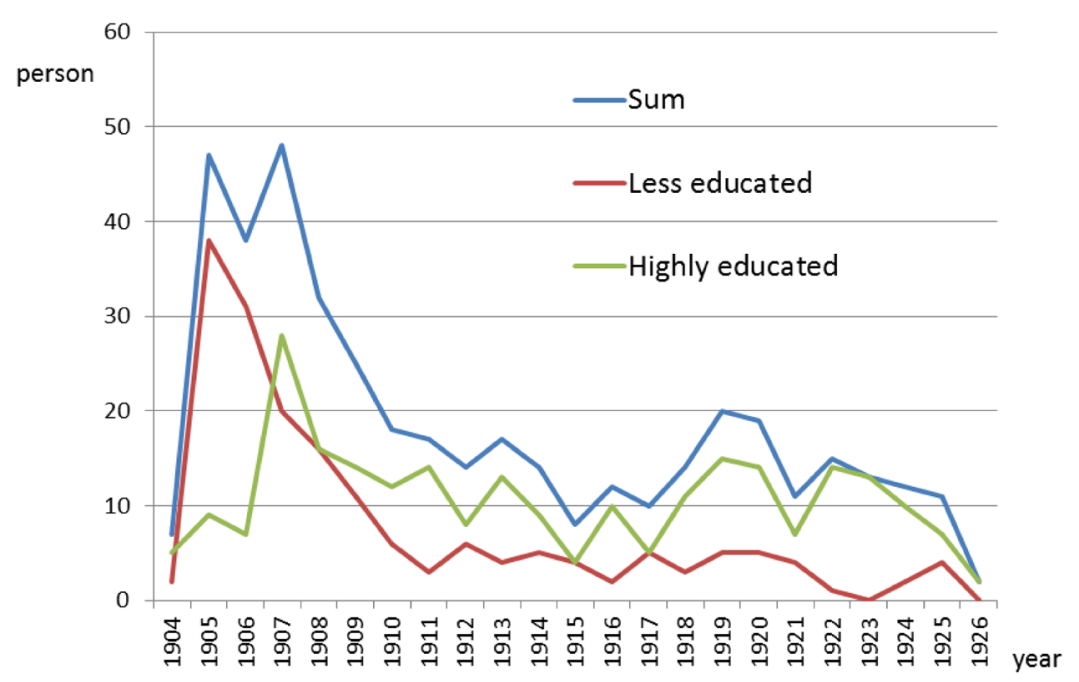

Figure 4. First year when people came to Dalian. Source: Manshu-shinshi-shinshoroku.

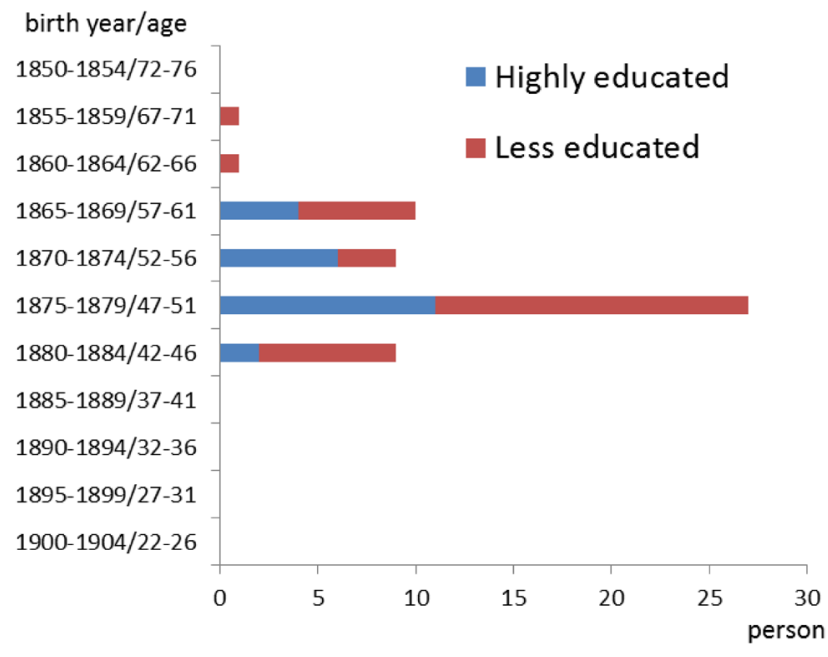

Figure 5. People involved in the Russo-Japanese War. Source: Manshu-shinshi-shinshoroku.

elites came from western Japan than eastern Japan (especially in the Yamaguchi and Saga prefectures by 1000 persons each), but the trend was not clear. Figure 7 shows the hometowns of less-educated people. These maps clearly indicate that western Japan (including Toyama prefecture) was represented more than eastern Japan.

The next figures show the professional backgrounds of the workers before their arrival in Dalian. In fact, their careers were complicated. In this study, I selected the main careers and prepared the career patterns. For example, in these cases (as mentioned below) where the career patterns were prepared, i.e., from company to company, and from store (or company) employee to independent business (owner), it includes the cases where changes were undertaken several times.

Figure 8 shows the career patterns for the highly educated group. The largest number of them moved "from company to company," the second-largest group moved "from government official to Mantetsu employee," and the third-largest group "immediately took a position in Mantetsu after graduating from school." Others "worked in one company (no change)" or moved from "company to independent business."

Figure 9 shows the professional trajectories of the lesseducated group. The largest group moved "from store (or company) employee to independent business (owner)," the second-largest "from the start, ran independent businesses." Those two patterns were dominant.

The professional turning points leading to work in Dalian varied between the highly educated and less-educated groups. Most of the highly educated people took positions in companies or government offices just after graduating from school. Thus, the turning point in their lives was entry into college, university, or higher professional school, and the geographical locations of these turning points were the locations of their schools. Figure 10 shows by prefecture the schools attended by highly educated elites. ${ }^{1}$ This map shows Tokyo to be highly significant because Tokyo had many schools at that time. Other significant locations included Kyoto, Hyogo (where Kobe is located), Osaka, and Nagasaki.

The pivotal locations for less-educated workers were the locations of the stores (or companies) where they worked or where they started their own businesses before arriving in Dalian by leaving their hometowns. Figure 11 shows these locations by prefecture. ${ }^{2}$ Osaka proved to be most important, followed by Tokyo, Hyogo (where Kobe is located), and Fukuoka (where Moji is located). When I look nationwide, as Kobe being closer to Osaka, OsakaKobe (Hanshin) area had a very important meaning.

Finally, we identified the foreign places where the workers had engaged in businesses for their intention 

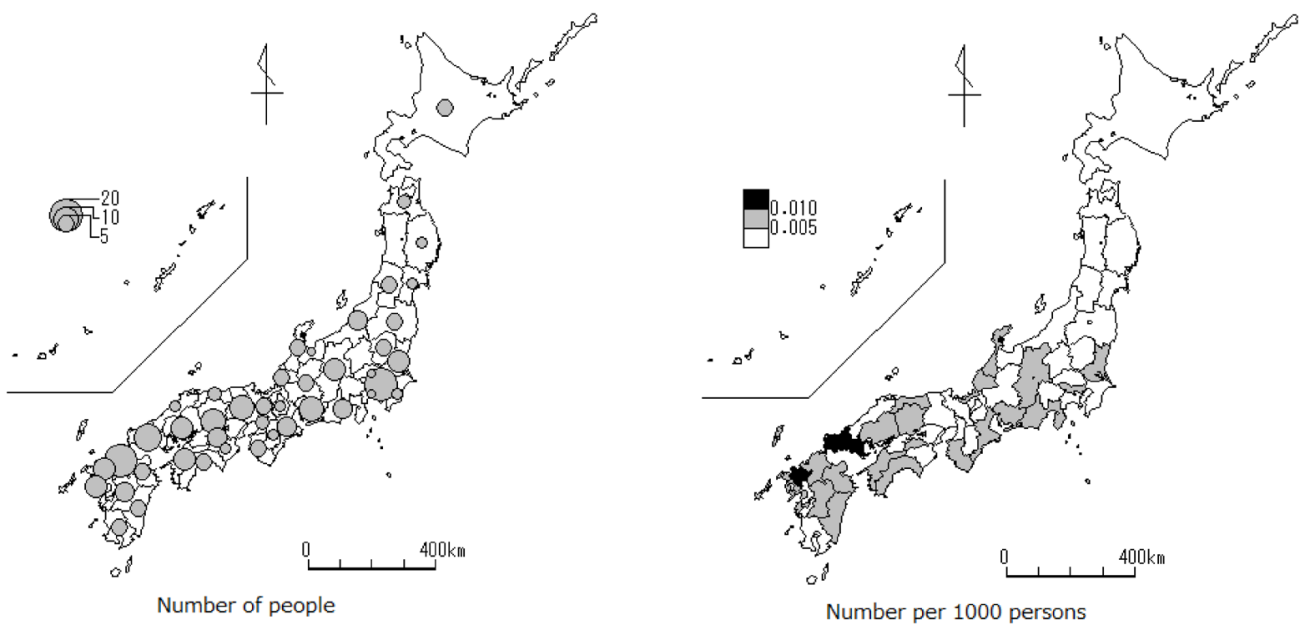

Figure 6. Hometown (highly educated).

Source: Manshu-shinshi-shinshoroku.
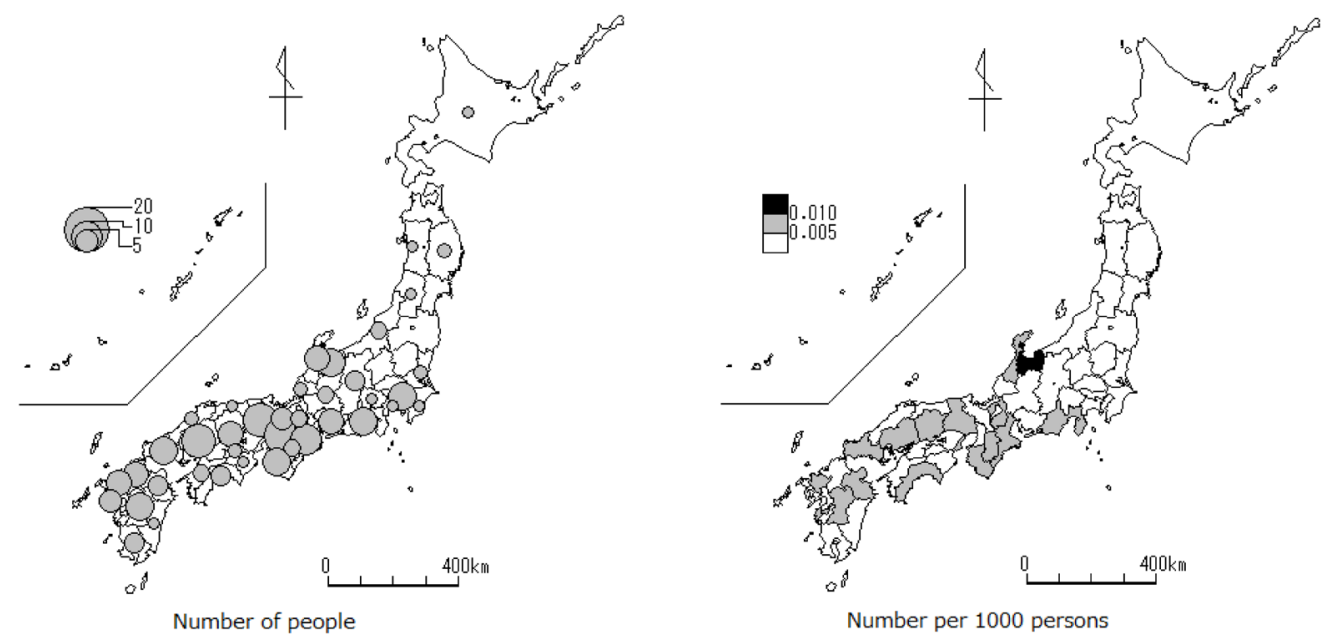

Figure 7. Hometown (less educated).

Source: Manshu-shinshi-shinshoroku.

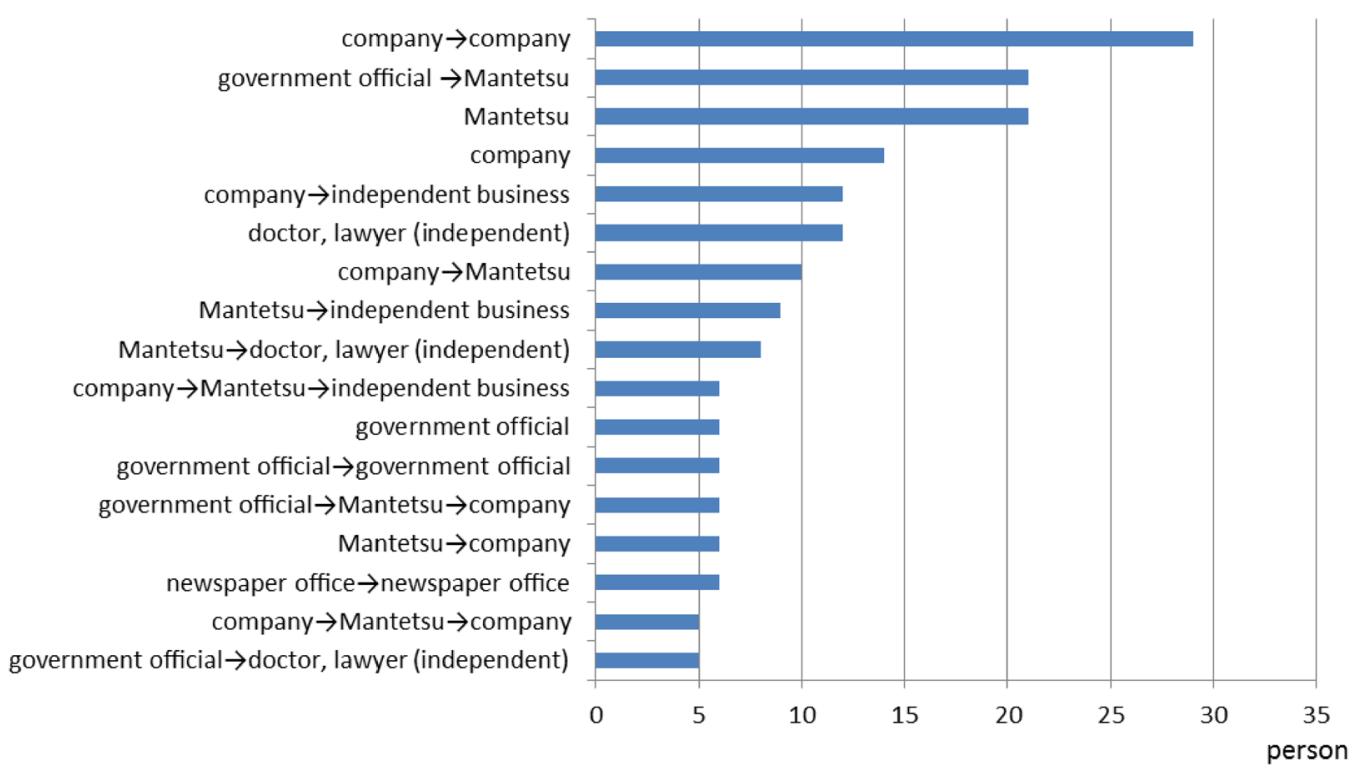

Figure 8. Patterns of career (highly educated).

Source: Manshu-shinshi-shinshoroku. 


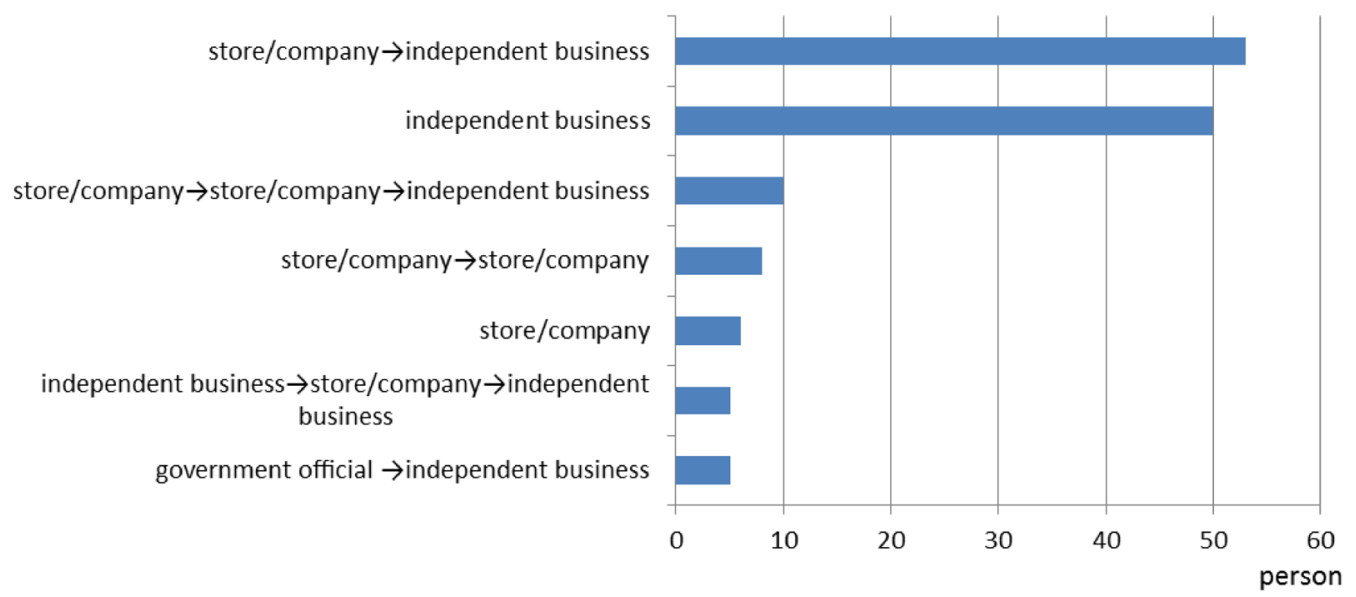

Figure 9. Patterns of career (less educated).

Source: Manshu-shinshi-shinshoroku.

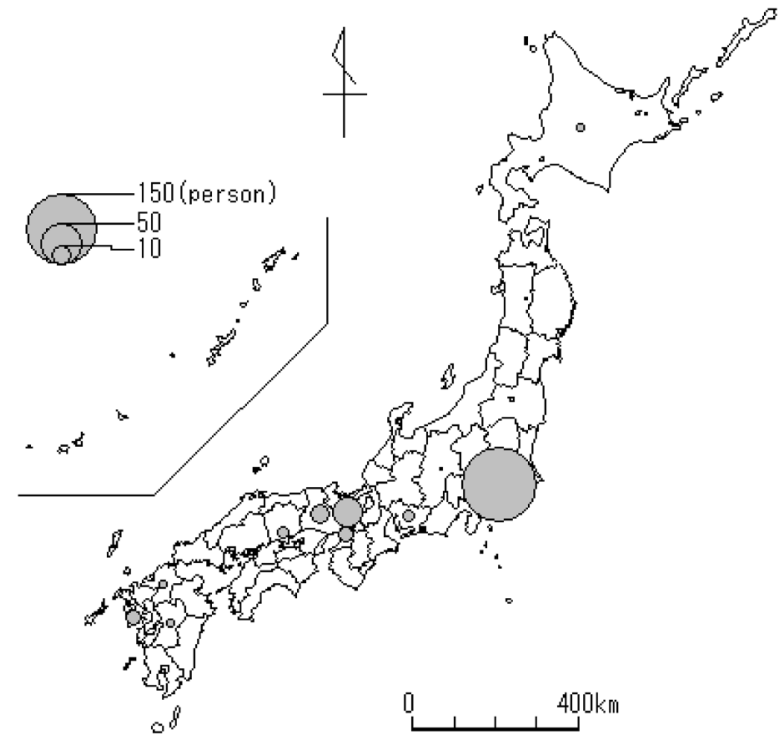

Figure 10. Location of the schools attended by highly educated people.

Source: Manshu-shinshi-shinshoroku.

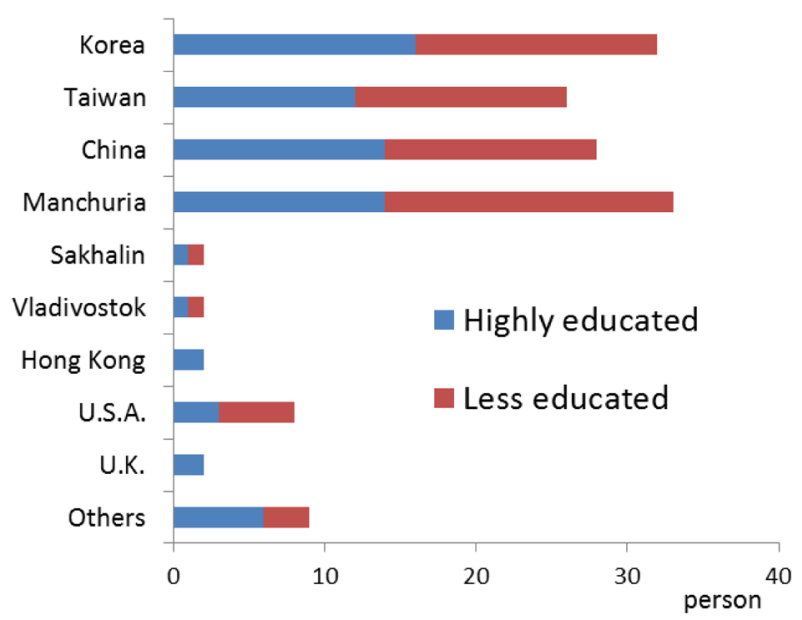

Figure 12. Foreign places where people had worked. Source: Manshu-shinshi-shinshoroku.

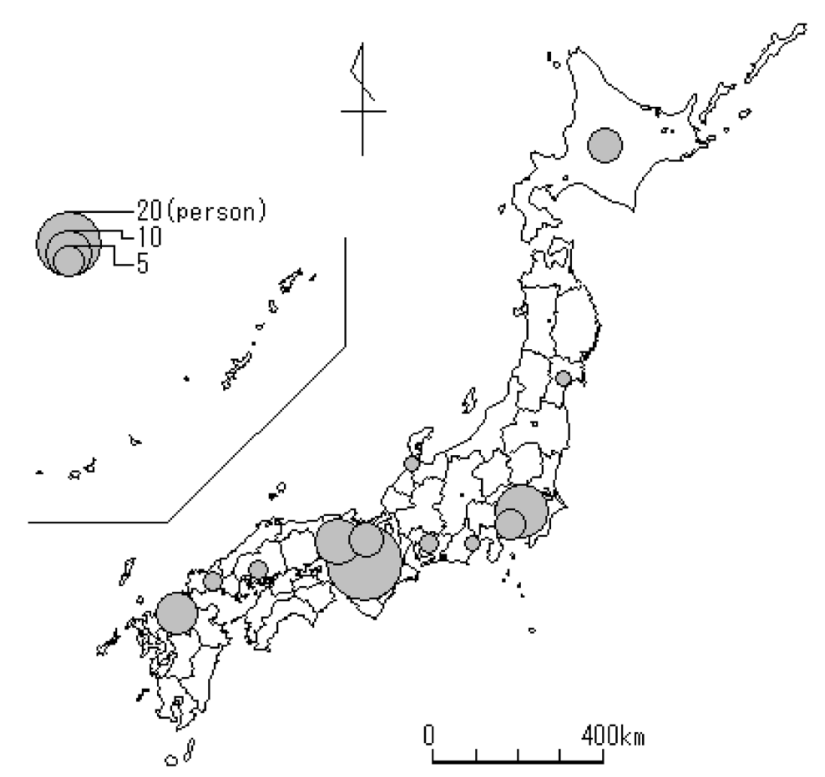

Figure 11. Locations in the mainland where less-educated people worked.

Source: Manshu-shinshi-shinshoroku.

before they succeeded in Dalian. These are shown in Figure 12. This figure shows the total number of places they went to. The figure shows little difference between the highly educated and less-educated groups relatively. The most common places they had conducted business were Korea, Taiwan, China, and Manchuria (apart from Dalian). The total number of the places they had worked overseas was 144, and the total number of individuals was 116. This indicates that one person moved to several places, and this group comprised 27 percent of all workers examined in the study.

\section{Examples of Successful Japanese Businessmen and Elites}

In this chapter, I will present the example of influential 
persons in order to join the individual factors examined, such as hometown, career, and pivotal locations.

I selected five people from among the highly educated group and five from the less-educated group. First, I chose the people from the age group (37-51) who excelled according to age structure, as shown in Figure 2. Second, I showed representative career patterns and types of business, as shown in Figures 8 and 9 and Table 1 , by choosing people who had some connection to the Russo-Japanese War, as shown in Figure 5, and the foreign places where they had worked, as shown in Figure 12. In addition, I considered the location of the schools, the location of the mainland where they had worked, and their hometown.

In this way, I chose 10 subjects and showed their characteristics in Table 2. I briefly describe the life courses shown in the data of Table 2 before each person succeeded in Dalian.

First, I describe the highly educated subjects in order of their age in the table.

Nakamura was born in Yamaguchi and found a job at the Railway Bureau after graduating from Tokyo Imperial University. He engaged in the construction of a railroad for war at the time of the Russo-Japanese War. After the war, he moved to Mantetsu and became an office manager of the temporary railroad construction.

Hori was born in Oita and found a job at the construction office of the Osaka city port after graduating from Kyoto Imperial University. He was then employed by Mantetsu as an engineer and engaged in the maintenance business of the Dalian port becoming a sectional chief of the wharf construction office of Mantetsu.

Oguri was born in Aichi and graduated from Waseda University in Tokyo. After that, he found a job in the provincial bank in Aichi and changed his job to the Nisshin oil mills company. In the company, at first he worked in the Yingkou branch and moved to the Dalian branch. After having worked in the head office of Yokohama for a time, he began to work at the Dalian branch again. Then, he entered the chemical industry company as a managing director when it was established in Dalian.

Hyodo was born in Ehime and graduated from Nagasaki higher-commercial school. He was interested in Korea after Japan annexed it and found a job in the local agricultural and industrial bank in Korea. When Manchurian bank was established, he came to Dalian and

Table 2. Example of Successful Businessmen and Elites

\begin{tabular}{|c|c|c|c|c|c|c|c|c|c|c|}
\hline & $\begin{array}{l}\text { Family } \\
\text { name }\end{array}$ & $\begin{array}{l}\text { Birth } \\
\text { year }\end{array}$ & $\begin{array}{l}\text { Birth place } \\
\text { (Prefecture) }\end{array}$ & Patterns of career & $\begin{array}{l}\text { Location } \\
\text { of schools } \\
\text { attended }\end{array}$ & $\begin{array}{l}\text { Location of } \\
\text { employment } \\
\text { in the } \\
\text { mainland }\end{array}$ & $\begin{array}{c}\text { Foreign } \\
\text { locations } \\
\text { where they } \\
\text { had worked }\end{array}$ & $\begin{array}{c}\text { Occupation } \\
\text { with the } \\
\text { Russo- } \\
\text { Japanese War }\end{array}$ & $\begin{array}{l}\text { Types of } \\
\text { business } \\
(1926)\end{array}$ & $\begin{array}{c}\text { Position in } \\
\text { the business } \\
\text { (1926) }\end{array}$ \\
\hline \multirow[t]{5}{*}{$\begin{array}{l}\text { Highly } \\
\text { educated }\end{array}$} & Nakamura & 1875 & Yamaguchi & $\begin{array}{c}\text { Government } \\
\text { official } \rightarrow \text { Mantetsu }\end{array}$ & Tokyo & Tokyo & - & $\begin{array}{c}\text { Civilian war } \\
\text { worker }\end{array}$ & Mantetsu & $\begin{array}{c}\text { Office } \\
\text { manager }\end{array}$ \\
\hline & Hori & 1880 & Oita & $\begin{array}{c}\text { Government } \\
\text { official } \rightarrow \text { Mantetsu }\end{array}$ & Kyoto & Osaka & - & - & Mantetsu & $\begin{array}{l}\text { Sectional } \\
\text { chief }\end{array}$ \\
\hline & Oguri & 1882 & Aichi & Company $\rightarrow$ company & Tokyo & Aichi & $\begin{array}{l}\text { Manchuria } \\
\text { (Yingkou) }\end{array}$ & - & Manufacturer & $\begin{array}{l}\text { Managing } \\
\text { director }\end{array}$ \\
\hline & Hyodo & 1885 & Ehime & Company $\rightarrow$ company & Nagasaki & - & Korea & - & Bank & $\begin{array}{l}\text { Branch } \\
\text { manager }\end{array}$ \\
\hline & Unoki & 1889 & Saga & Company & Kobe/Tokyo & $\begin{array}{c}\text { Tokyo/Kobe/ } \\
\text { Moji }\end{array}$ & - & - & $\begin{array}{l}\text { Transport } \\
\text { industries }\end{array}$ & $\begin{array}{l}\text { Branch } \\
\text { manager }\end{array}$ \\
\hline \multirow[t]{5}{*}{$\begin{array}{l}\text { Less } \\
\text { educated }\end{array}$} & Ota & 1878 & Shizuoka & $\begin{array}{c}\text { Store/ } \\
\text { company } \rightarrow \text { independent } \\
\text { business }\end{array}$ & - & Tokyo & - & - & Manufacturer & $\begin{array}{c}\text { Independent } \\
\text { manager }\end{array}$ \\
\hline & Ishimitsu & 1878 & Hiroshima & Independent business & - & Hiroshima & $\begin{array}{c}\text { Taiwan/Korea/ } \\
\text { Manchuria }\end{array}$ & War broker & $\begin{array}{c}\text { Store/ } \\
\text { construction }\end{array}$ & $\begin{array}{c}\text { Independent } \\
\text { manager }\end{array}$ \\
\hline & Hara & 1881 & Hyogo & Independent business & - & Osaka & - & - & construction & $\begin{array}{c}\text { Independent } \\
\text { manager }\end{array}$ \\
\hline & Uritani & 1883 & Toyama & $\begin{array}{c}\text { Store/ } \\
\text { company } \rightarrow \text { independent } \\
\text { business }\end{array}$ & - & Kobe & - & - & Store & $\begin{array}{c}\text { Independent } \\
\text { manager }\end{array}$ \\
\hline & Tachibana & 1884 & Kumamoto & $\begin{array}{c}\text { Store/ } \\
\text { company } \rightarrow \text { independent } \\
\text { business }\end{array}$ & - & Moji & - & Soldier & Store & $\begin{array}{c}\text { Independent } \\
\text { manager }\end{array}$ \\
\hline
\end{tabular}


entered the company, becoming a branch manager.

Unoki was born in Saga and graduated from Kobe higher-commercial school. Furthermore, he graduated from the specialty department of Tokyo higher-commercial school and received his Bachelor's. Then, he entered Yamashita steamship company and worked in Tokyo and Kobe. He worked in the branch office of Moji and moved to the Dalian branch office, becoming the branch manager.

Next, I describe the less-educated persons in the order of age.

Ota was born and raised in Shizuoka but found a job with a printing company in Tokyo. When the branch of the company was established in Dalian, he became its branch manager. He then became an independent printer.

Ishimitsu was born in Hiroshima and ran a building contracting business under his older brother. He then went to Taiwan and worked as war broker after which he moved to Korea. At the time of the Russo-Japanese War, he became war broker in Yingkou and started a building contracting business and developed branches in Manchuria. Meanwhile, he moved to the head office in Dalian. He came to start a merchant business and building trades in Dalian.

Hara was born in Hyogo, and his family ran a building contracting business. He moved to Osaka to run the same business. Meanwhile, because many people around him began to move to Manchuria after the Russo-Japanese War, he moved to Dalian and ran a building contracting business.

Uritani was born in Toyama and found a job in a store at Kobe. When the store established a branch office in Dalian, he moved to Dalian as the office chief. He then became an independent merchant.

Tachibana was born in Kumamoto and graduated from the commercial school of Kumamoto. Then, he joined Mitsui \& Co., but he was drafted for Russo-Japanese War. He worked in the Moji branch of Mitsui \& Co. after being discharged from military service. Afterward, he was assigned to the Dalian branch and moved to Dalian. Meanwhile, he began to run an import trade business independently.

\section{Conclusion}

The current study's findings on the occupation constitution of Dalian and Mantetsu having played an important role as the workplace generally accord with the opinions of Yanagisawa (1999) and Tsukase (2004). The fact the many hometowns of successful Japanese businessmen and elites were located in western Japan, is in agreement with the opinion that Avila-Tàpies (2002) and Komine (2010) pointed out concerning the people who moved to Manchuria. In addition, for the highly educated people, the school's location played a pivotal role in their life, and therefore, it may be said that Tokyo was the most significant location for them because there were many schools located there in those days.

The current study shows not only that many hometowns of the successful Japanese businessmen and elites were located in western Japan but also that this tendency was strongest among less-educated workers. In addition, I point out the new data that Osaka-Kobe area was the most significant location for the less-educated workers. This is because Osaka was the center of commerce in Japan at the time, in addition to the fact that shipping traffic between Osaka-Kobe and Dalian was convenient.

Figure 13 simplifies the migration spatial patterns to Dalian to consider relations between the Japanese mainland and the colony on the basis of the result of the pres-

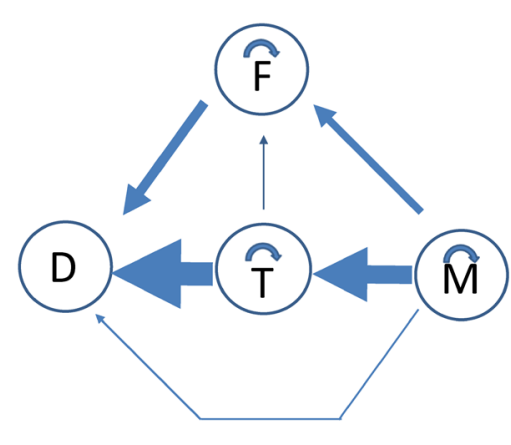

Highly educated

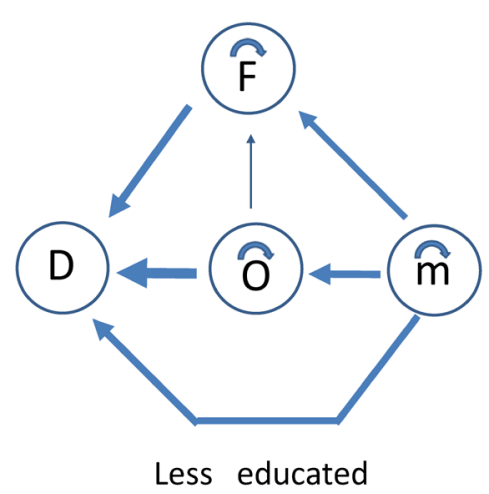

Less educated

D: Dalian. F: Foreign places. T: Tokyo, Kyoto, Hyogo, Osaka, and Nagasaki.

O: Osaka, Tokyo, Hyogo, and Fukuoka. M: Prefectures in Japanese mainland except "T".

$\mathbf{m}$ : Prefectures in Japanese mainland except "O".

Figure 13. Spatial patterns of migration to Dalian. 
ent study. As shown in the explanatory notes in the figure, " $\mathrm{D}$ " means Dalian and " $\mathrm{T}$ " means the prefectures where highly educated people attend school (Tokyo, Kyoto, Hyogo, Osaka, and Nagasaki). "F" indicates the foreign places shown in Figure 12 that were mainly Japanese colonies. " $\mathrm{M}$ " denotes the prefectures in the mainland except "T".

Likewise, "O" refers to the pivotal prefectures in the mainland for less-educated people (Osaka, Tokyo, Hyogo, and Fukuoka), and " $m$ " means the prefectures in mainland except "O". The arrows in the figure show the movement, and the thickness expresses the large and small numbers. In addition, the turned arrows depict the movements within each area. In fact, there were the movements that are not expressed in the arrows, for example, the movements from "T" to " $\mathrm{M}$ ", from "O" to " $\mathrm{m}$ ", and from " $F$ " to "M" or " $m$ ". Because I placed more emphasis on the movement to Dalian as the last destination of the people in this figure, I omitted the movement of those people.

The main movement patterns of highly educated people were that they moved from the local mainland to Tokyo and so on and then moved toward Dalian. There were also comparatively many movements of people who went from the local mainland to a foreign country and then moved toward Dalian. On the contrary, few movements were noticed for people who directly went to Dalian from the local mainland. In the case of lesseducated people, many moved from the local mainland to Osaka or other places and then moved toward Dalian. In addition, there were many people who went directly to Dalian from the local mainland or to a foreign country once and thence to Dalian.

Thus, in terms of population migration of successful Japanese businessmen and elites, Dalian was formed under such regional relationships between the mainland and other colonies.

\section{Notes}

1. It should be kept in mind that 17 people attended schools in foreign countries.

2. It should be kept in mind that this figure does not indicate the cases they worked or the businesses they started in their hometowns.

\section{References}

Avila-Tàpies, R. 2002. Kindai ni okeru kyu Manshu he no nihonjin no iju oyobi sono teichaku patan ni tsuite. (Japanese immigration to the former territory of Manchuria and its settlement patterns (1906-45)). Journal of Konan University, Faculty of Letters 129: 34-59. (JS)

Avila-Tàpies, R. 2003. Kyu Manshu ni okeru minzoku-kan no kyoju bunka no jokyo (jo): Minami Manshu Testudo fuzokuchi toshi no jirei. (The residential segregation by ethnic groups in colonial Manchuria: The case of the cities of the South Manchuria Railway (first part)). Journal of Konan University, Faculty of Letters 134: 3-19. (JS)

Avila-Tàpies, R. 2004. Kyu Manshu ni okeru minzoku-kan no kyoju bunka no jokyo (ge): Minami Manshu Tetsudo fuzokuchi toshi no jirei (The residential segregation by ethnic groups in colonial Manchuria: The case of the cities of the South Manchuria Railway (second part)). Journal of Konan University, Faculty of Letters 139: 193-208. (JS)

Avila-Tàpies, R. 2013. Imperial expansion, human mobility and the organization of urban space in Manchuria (Part I). Social Sciences (Institute for the study of Humanities and Social Sciences, Doshisha University) 43(3): 35-56.

Komine, K. 2010. Manshu-Shinshiroku no kenkyu. Tokyo: Yoshikawa-kobunkan. (J)

Miki, M. 2013. A study of the relationship between the South Manchurian Railway and freight shipments of soybeans in Manchuria before the 1920s. Japanese Journal of Human Geography 65: 107-128. (JE)

Mizuuchi, T. 1985. Formation and development of a Japanese colonial city: Dalian from 1899 to 1945. Japanese Journal of Human Geography 37: 438-455. (JE)

Nakanishi, R. 2006. 1900-1920 nendai no "Minami Manshu" ni okeru chiiki keizai: Ryoyou-ken no yushutsunyu-hin no bunseki. (Regional economy in southern Manchuria from the 1900s to the 1920s: A case study on the exports and imports in Liaoyang prefecture). Geographical Reports of Chiba University 17: 31-44. (J)

Tsukase, S. 2004. Manshu no nipponjin. Tokyo: Yoshikawakobunkan. (J)

Yanagisawa, A. 1999. Nipponjin no Shokuminchi-keiken (The Japanese and colony: Living and earning of Japanese colonists in Dalian 1905-1947). Tokyo: Aoki Shoten. (J)

(J) written in Japanese

(JE) written in Japanese with English abstract

(JS) written in Japanese with Spanish abstract 